\title{
Effect of Foliar Fungicides on Haill-damaged Corn
}

\begin{abstract}
Adam J. Sisson, Yuba R. Kandel, and Alison E. Robertson, Department of Plant Pathology and Microbiology, Iowa State University, Ames 50011; Chad E. Hart, Department of Economics, Iowa State University, Ames 50011; Amy Asmus, Asmus Farm Supply, Rake, IA 50465; Stith N. Wiggs and Daren S. Mueller, Department of Plant Pathology and Microbiology, Iowa State University, Ames 50011
\end{abstract}

Accepted for publication 7 January 2016. Published 13 January 2016.

\section{ABSTRACT}

Sisson, A. J., Kandel, Y. R., Robertson, A. E., Hart, C. E., Asmus, A., Wiggs, S. N., and Mueller, D. S. 2016. Effect of foliar fungicides on hail-damaged corn. Plant Health Prog. 17:6-12.

To test if fungicide applied to hail-injured corn improves yield and reduces disease, we simulated hail at VT and R2 growth stages for three years at three Iowa locations for a total of five site years. Hail damage was simulated using a string trimmer or an ice-propelling machine and non-hail controls were included. Estimated defoliation ranged from 5 to $51 \%$, along with ear and stalk injury. After hail events, Headline AMP fungicide (pyraclostrobin + metconazole) was applied at an "immediate" or "deferred" timing (averaging 3 and 8 days afterwards, respectively). A non-fungicide treated control was included in hailed and non-hail control plots. Hail injury reduced fungal foliar disease compared to plants without hail injury, although overall disease severity was low during this study. Hail events at VT or R2 decreased yield compared to control plots $(P=0.1)$. Fungicide application did not provide yield-increasing plant health benefits after VT and R2 hail, at either "immediate" or "deferred" timing. While yield differences were not statistically significant, a cost/benefit analysis showed deferred fungicide application after VT hail, and immediate and deferred applications after VT for non-hail plots did provide positive economic returns. Results will help inform decisions about fungicide use in hail-damaged corn when foliar diseases are not present at high levels.

\section{INTRODUCTION}

Iowa is the top corn (Zea mays) producing state in the United States, with 13.6 million acres planted and an estimated value of more than $\$ 10$ billion in 2013 (USDA-NASS, State Agricultural Overview). The number of acres planted to corn across the North Central region of the United States was nearly 78.5 million in 2013 , which accounted for about $82 \%$ of total U.S. acres that year (USDA-NASS Quick Stats 2.0). Over the past decade, fungicide application to these acres has increased dramatically for a variety of reasons including better grain prices, increased risk of disease, and product marketing. Before 2006, foliar fungicide applications to corn occurred rarely (Fernandez-Cornejo et al. 2014); as of 2011, foliar fungicides were applied to 10 million U.S. corn acres (Wise and Mueller 2011). Instead of viewing fungicide use as an emergency or situation-specific management option for fungal diseases (Paul and Munkvold 2004), fungicides are currently considered for use even in the absence of disease.

Hail injury to corn can seem like an isolated phenomenon, occurring on only a few acres each year. However, hail annually destroys approximately $1.4 \%$ of planted corn in Iowa (NOAANCDC 2006). This translates into 190,400 acres of Iowa corn destroyed by hail in 2013 . More than 1 million Iowa corn acres were affected by strong hail storms in 2009 alone (Robertson et al. 2011). Estimated annual economic losses to U.S. corn farmers from hail over a five-year period starting in 2003 were 36 to nearly 60 million dollars (Bradley and Ames 2010).

Fungicide application is promoted as a proactive measure for, and a response to, hail injury in corn (BASF Corporation 2008b,

Corresponding author: Daren Mueller. Email: dsmuelle@iastate.edu

doi:10.1094/PHP-RS-15-0046

(C) 2016 The American Phytopathological Society
2009). This is based on the idea that the physiological benefits gained from a fungicide application will help to preserve and aid recovery of the damaged crop. This consideration is backed by supplemental labeling available for Headline (pyraclostrobin), which reports plant health benefits in addition to disease control (BASF Corporation 2008a). It is claimed that these plant health benefits result in higher yield potential for corn. Quilt Xcel and Stratego YLD fungicide labels also claim "plant performance" or "plant health" benefits (Syngenta Crop Protection 2013; Bayer CropScience 2012).

Farmers are also advised to apply foliar fungicides to haildamaged crops based on the idea that disease infection is more likely to occur with the wounds caused by hail (BASF Corporation 2009; French-Monar 2010; Jackson-Ziems 2014; Hefty 2013). However, wounding is not required for the fungal diseases that are managed by foliar-applied fungicides including gray leaf spot (Cercospora zeae-maydis), northern corn leaf blight (Setosphaeira turcica), and others (White 1999). Diseases such as Goss's wilt (Clavibacter michiganensis subsp. nebraskensis), caused by a bacterium, are favored by plant tissue damage, but fungicides are not active against this pathogen.

In the few replicated studies conducted on corn injured by hail, no significant yield responses have been observed from application of fungicides either before (Conley et al. 2010) or after a hail event (Schleicher and Jackson-Ziems 2014; D. Smith personal communication). Because these studies were initiated in response to unexpected hail injury, a non-hail-damaged check was unavailable. This check is required to compare the effect of a fungicide on both hail-damaged and non-hail-damaged crops at the same site. To date, the only controlled comparison of fungicide effects on damaged corn was undertaken by Bradley and Ames (2010) using a string trimmer to simulate hail on corn at VT (Abendroth et al. 2011). This two-year study found no fungicide effect on yield in injured or uninjured plots. It did not 


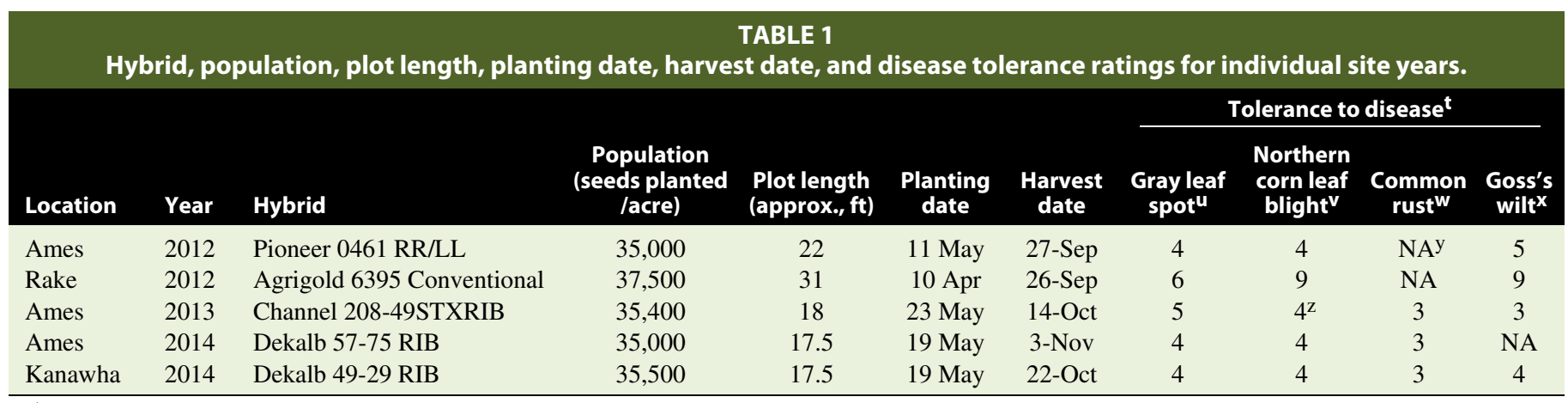

${ }^{\mathrm{t}}$ Self-reported by seed companies. Rating scales between seed companies are not necessarily equivalent, and are as follows. Pioneer: " $9=$ excellent, 1 = poor." Agrigold: "The higher the number the better the performance, or stronger the tolerance." Channel: " $1=$ excellent, $9=$ poor." Dekalb = " $1=$ excellent, 9 = poor."

${ }^{\mathrm{u}}$ Cercospora zeae-maydis

$\checkmark$ Setosphaeira turcica

${ }^{w}$ Puccinia sorghi

${ }^{\mathrm{x}}$ Clavibacter michiganensis subsp. nebraskensis

${ }^{\mathrm{N}} \mathrm{NA}=$ not available

${ }^{\mathrm{z}}$ This rating specific to Race 1; no rating given for Race 2.

examine simulated hail damage at different growth stages or timing of fungicide application after a simulated hail event.

The goal of this study was to determine if there was a benefit of a fungicide application to hail-damaged corn. Therefore, the objectives were to: (i) examine the effect of hail damage at two mid-season (VT and R2) growth stages on foliar disease severity and yield; and (ii) to determine if a fungicide applied after hail damage at an "immediate" or "deferred" timing reduced foliar disease severity or improved yield. In addition to comparing yield and disease results, we also considered the profitability of fungicide use in hail-damaged corn.

\section{FIELD EXPERIMENTS}

Experimental plots were established at Asmus Farm Supply near Rake, IA, in 2012; the Iowa State University (ISU) Agricultural Engineering and Agronomy Farm near Ames, IA, in 2012, 2013, and 2014; and the ISU Northern Research Farm in Kanawha, IA, in 2014 for a total of five site years. At each location, the experimental design was a $3 \times 3$ factorial with controls in randomized complete block with four replications. Plots consisted of four 30-inch rows of corn at least $17.5 \mathrm{ft}$ long, with disease and yield data obtained from the middle two rows. Plots were organized in multiple rows with a drive row on at least one side of the plot to allow for movement of machinery each site year except at Rake in 2012, where plots were embedded within larger, 12-row sections. Plots within a row were separated by at least $2 \mathrm{ft}$ from other subplots by mechanically removing plants or by not seeding this area during planting. Hybrid, population, plot length, planting date, harvest date, and hybrid foliar disease tolerance ratings varied by site year (Table 1 ).

The simulated hail treatment was applied at or near VT and R2 corn growth stages (Abendroth et al. 2011) each year (Table 2) using gas-powered string trimmers in 2012 and 2013 (Husqvarna, unknown model; Stihl, FS100RX) or a custom-built, PTOpowered ice applicator in 2014 (a video of hail application is available at http://www.news.iastate.edu/video/view/id/ cwhtyeuijok). The PTO-powered applicator had the ability to better simulate actual hail injury by propelling ice cubes (commonly available from grocery stores in bags of $20 \mathrm{lbs}$ or less) from above and to the side of plants fast enough to cause more realistic impacts to leaves, ears, and stalks. A no-hail treatment was included in the study as a control. When the iceapplicator was used, the outer two rows of hailed plots were subjected to hail simulation using a weed trimmer to limit the

\begin{tabular}{ll} 
TABLE 2 \\
$\begin{array}{r}\text { Two hail and two fungicide factors, along with untreated } \\
\text { controls for each factor, totaled } 11 \text { treatments. }\end{array}$ \\
\hline Hail application factor & Fungicide application factor \\
\hline None & None \\
None & VT $^{\mathrm{w}}$ Immediate \\
None & VT Deferred $^{\mathrm{x}}$ \\
None & R2 $^{\mathrm{z}}$ Immediate \\
None & R2 Deferred \\
VT & None \\
VT & VT Immediate \\
VT & VT Deferred \\
R2 & None \\
R2 & R2 Immediate \\
R2 & R2 Deferred \\
\hline
\end{tabular}

${ }^{\text {w }}$ Corn growth stage VT ("tasseling").

${ }^{\mathrm{x}}$ Immediate $=$ applications were sprayed 2 to 6 days (averaging 3 days) after a simulated hail event.

${ }^{\mathrm{y}}$ Deferred $=$ applications were sprayed 7 to 12 days (averaging 8 days) after a simulated hail event.

${ }^{\mathrm{z}}$ Corn growth stage R2 ("blister").

transport of large amounts of ice. This was done to diminish the impact on non-damaged rows affecting the middle two data rows.

The fungicide treatments were applications of the commercial fungicide Headline AMP (pyraclostrobin and metconazole; BASF Corporation, Research Triangle Park, NC; 10 fl oz/acre).

Fungicide was applied using either a self-propelled sprayer (Ames 2012-2014 at 16 gal/acre water volume; Rake 2012 at 1720 gal/acre water volume) or a $\mathrm{CO}_{2}$-powered backpack applicator with an overhead boom extending to the top of the plants (Kanawha 2014 at 20 to $25 \mathrm{gal} /$ acre water volume). In total, there were 11 treatments, including the controls (Table 2). Two fungicide timings were compared within VT and R2 growth stage hail factors: (i) "Immediate" applications were sprayed 2 to 6 days (averaging 3 days) after a simulated hail event; and (ii) "Deferred" applications were sprayed 7 to 12 days (averaging 8 days) after a simulated hail event (Table 3). A no-fungicide treatment was included as a control.

\section{DATA COLLECTION}

Simulated hail injury to plants was assessed for each hail event in 2012 by estimating percent of missing leaf tissue on 7 to 12 arbitrarily chosen leaves on each of 9 plants. Results were 
averaged to determine an overall estimated defoliation injury level for hailed plots in that field. In 2013, defoliation was visually estimated in 13 and 12 of the plots receiving VT and R2 hail, respectively. Estimates were averaged to obtain a single value for each hail event. In 2014, defoliation was determined by examining plants in plots with hail injury and estimating percent missing leaf tissue. The number of days elapsed between simulated hail injury and assessment varied depending on location and event (Table 4).

Foliar disease assessment occurred once each season on 21 August, 17 August, 11 and 13 September, 3 September, and 4 September at Ames 2012, Rake 2012, Ames 2013, Ames 2014, and Kanawha 2014, respectively, when corn plants were at approximately R5 growth stage. Visual estimates of disease severity of fungal diseases were collected from the ear leaf of five consecutive plants near the center of both middle rows $(\mathrm{n}=10$ plants). Since leaf injury sustained during simulated hail sometimes resulted in very little leaf tissue remaining attached to the plant, it was not always possible to assess disease on the ear leaf. When this occurred, the next leaf above the ear leaf with enough foliage was rated. Other diseases and issues were noted to identify possible yield-limiting factors.

At maturity, plots at Ames in 2012 and 2013 were harvested using a modified John Deere 4400 combine (Deer \& Company, Moline, IL) with a custom-built weigh-bucket system with an electronic load cell (Avery Weigh-Tronix LLC, Fairmont, MN). Plots at Ames in 2014 were harvested using a modified John Deer 9450 combine utilizing a HarvestMaster GrainGage (Juniper Systems, Inc., Logan, UT). Plots at Kanawha were harvested using a modified John Deere 9410 with a HarvestMaster GrainGage. Plots at Rake were harvested with a plot combine (unknown make and model) and grain weight was determined using a weigh wagon; moisture was determined post harvest using a GAC2100 (DICKEY-john Corporation, Auburn, IL). Harvest weight was adjusted to $15.5 \%$ moisture content and yield was extrapolated to bushels per acre.

\section{ECONOMIC METHODS}

To examine the economic costs/benefits of the fungicide applications, the data for each plot were evaluated given the following prices and cost. The corn price was set at $\$ 3.43 / \mathrm{bu}$, the price reported by USDA-AMS in their "Interior Iowa Daily Grain Prices" report on 6 August 2015. Cost for the fungicide in the application was based on a fungicide value of $\$ 250.00 / \mathrm{gal}$ or $\$ 19.53$ per treatment. The application cost was taken from the 2015 Iowa Farm Custom Rate Survey for aerial spraying, $\$ 10.60 /$ acre. Thus, the economic analysis compares the financial benefit of the application, a product of the corn price and the yield difference between the treatment and the control, and the financial cost of the application, which is the sum of the fungicide and application costs. The average economic return of the treatments was calculated, along with the probability of a positive economic return.

\section{STATISTICAL ANALYSIS}

ANOVA was performed using PROC GLIMMIX in SAS (SAS Institute Inc., Cary, NC). Fixed effect factors were treatments (hail and fungicide). ANOVA was performed for individual site years across a hail event to compare among hail events and replication within hail event was used as random factor. Fungicide treatments were also examined within each site year by hail event where fungicide was used as fixed and replication was used as random effect factor. Means were compared using Fisher's protected LSD at $P=0.1$.

\section{EFFECT OF HAIL ON CORN PLANTS}

A natural hail event occurred at two of the five locations in this study, Ames 2013 and Kanawha 2014. Hail occurred during a late vegetative growth stage the week of 22 July in Ames 2013, resulting in shredded leaves (although the actual leaf tissue loss was minimal), bruised stalks, and severe goosenecking occurred (data not shown). At Kanawha 2014, hail occurred at approximately V7 and resulted in shredded leaves and broken leaf midribs.

\begin{tabular}{|c|c|c|c|c|c|c|c|}
\hline \multirow{2}{*}{ Location } & \multicolumn{7}{|c|}{$\begin{array}{c}\text { TABLE } 3 \\
\text { VT and R2 growth stage hail application dates with corresponding fungicide application dates. }\end{array}$} \\
\hline & Year & VT hail & \multicolumn{2}{|c|}{ VT fungicide } & R2 hail & \multicolumn{2}{|c|}{ R2 fungicide } \\
\hline Ames & 2012 & $13 \mathrm{Jul}$ & $16 \mathrm{Jul}$ & $23 \mathrm{Jul}$ & $24 \mathrm{Jul}$ & $27 \mathrm{Jul}$ & $1 \mathrm{Aug}$ \\
\hline Rake & 2012 & $5 \mathrm{Jul}$ & $7 \mathrm{Jul}$ & $12 \mathrm{Jul}$ & $20 \mathrm{Jul}$ & $23 \mathrm{Jul}$ & 27 Jul \\
\hline Ames & 2013 & 2 Aug & 5 Aug & 9 Aug & 13 Aug & 15 Aug & 20 Aug \\
\hline
\end{tabular}

${ }^{\mathrm{z}}$ Approximate date of application.

\begin{tabular}{|c|c|c|c|c|c|c|c|}
\hline \multirow{2}{*}{ Location } & \multirow{2}{*}{\multicolumn{3}{|c|}{$\begin{array}{r}\text { TA } \\
\text { Date of hail assessment and elapsed day } \\
\qquad \mathbf{V T}^{\mathbf{x}} \text { hail plots }\end{array}$}} & \multicolumn{3}{|c|}{$\begin{array}{l}\text { IBLE } 4 \\
\text { ys between hail event and assessment date. }\end{array}$} & \\
\hline & & & & & & R2y hail plots & \\
\hline Ames & 2012 & $13 \mathrm{Jul}$ & $18 \mathrm{Jul}$ & 5 & $24 \mathrm{Jul}$ & 13 Aug & 20 \\
\hline Rake & 2012 & $5 \mathrm{Jul}$ & $20 \mathrm{Jul}$ & 15 & $20 \mathrm{Jul}$ & 6 Aug & 17 \\
\hline Ames & 2013 & 2 Aug & $25 \mathrm{Sep}$ & 54 & 13 Aug & $25 \mathrm{Sep}$ & 43 \\
\hline
\end{tabular}

${ }^{x}$ Corn growth stage VT ("tasseling").

y Corn growth stage R2 ("blister").

${ }^{\mathrm{z}}$ Missing data. 
Estimated defoliation caused by simulated hail treatments varied by location, year, and growth stage (Table 5). Simulating hail using a string trimmer resulted in an average estimate of $43 \%$ defoliation across six hail treatments in 2012 and 2013 (two hail treatments for each of three site years). String trimmers cut portions of leaves completely from the plant. When hail was simulated using the ice-propelling machine, leaf midribs were broken and tissue was tattered, but leaves generally remained attached to the plant. Field observations for hail treatments in 2014 revealed that simulating hail using the ice-propelling machine resulted in an average estimate of $7 \%$ defoliation in plots. Bruising was observed on stalks and ears when the icepropelling machine was used, while string trimmers caused injury by slashing ears and stalks. Injury to stalk and ears from trimmers and ice was not quantified but undoubtedly contributed to yield loss as actual loss in plots exceeded that estimated by defoliation alone (USDA-FCIC 2013).

\begin{tabular}{|clccc}
\multicolumn{5}{c}{ TABLE 5} \\
Estimated defoliation for each site year and growth stage. \\
Year & Location & $\begin{array}{c}\text { Growth } \\
\text { stage at hail } \\
\text { application }\end{array}$ & $\begin{array}{c}\text { Method used for } \\
\text { hail treatment }\end{array}$ & $\begin{array}{c}\text { Estimated } \\
\text { defoliation } \\
(\%))^{\mathbf{y}}\end{array}$ \\
\hline 2012 & Ames & VT & String trimmer & 39 \\
2012 & Ames & R2 & String trimmer & 51 \\
2012 & Rake & VT & String trimmer & 37 \\
2012 & Rake & R2 & String trimmer & 51 \\
2013 & Ames & VT & String trimmer & 43 \\
2013 & Ames & R2 & String trimmer & 39 \\
2014 & Ames & VT & Ice machine & 5 \\
2014 & Ames & R2 & Ice machine & 5 \\
2014 & Kanawha & VT & Ice machine & NA \\
2014 & Kanawha & R2 & Ice machine & 10 \\
\hline
\end{tabular}

y Only defoliation estimated. Stalk and ear injury not quantified.

${ }^{\mathrm{z}}$ Missing data.

\section{FOLIAR FUNGICIDE EFFECT ON LEAF DISEASE SEVERITY}

Foliar fungal disease severity in all five site years was low and averaged $1 \%$ across all treatments (Table 6). Fungicide did not reduce foliar disease severity in simulated hail-damaged plots at either "Immediate" or "Deferred" application times at any site year. In plots with no simulated hail injury at site years that did not receive natural hail, a foliar fungicide application generally reduced disease (Table 6). Fungicide timing had no effect on disease severity in any plots at Ames 2013 and Kanawha 2014, where natural hail occurred. Common rust (Puccinia sorghi) was the main foliar disease at most site years. For this analysis, we focused on fungal foliar disease ratings. Severity ratings of other diseases were low and did not significantly affect yield (data not shown).

When all fungicide treatments and untreated controls were combined within a hail event to compare the effect of simulated hail treatment on foliar disease severity, we found that simulated hail plots consistently had lower foliar fungal disease severity than respective non-hail controls in the three site years that did not receive natural hail (Table 7).

\section{EFFECT OF SIMULATED HAIL AND FUNGICIDE ON YIELD}

Overall, actual average yield loss due to simulated hail was $28 \%$ and $20 \%$ from string trimmers and propelled ice, respectively. Simulated hail at either VT or R2 growth stages significantly decreased yield by about $25 \%$ across all fungicide treatments and site years compared to control plots (Table 7). No significant increase in yield due to a fungicide treatment was detected in the hailed plots compared to the non-hail plots in any site year (Table 8).

\section{ECONOMICS OF FUNGICIDE APPLICATION TO HAIL- INJURED CORN}

Based on the prices and costs outlined earlier, the economic return to the fungicide application for each application was evaluated. Tables 9 and 10 detail the average returns of the fungicide applications and the percentage of applications that

\begin{tabular}{|c|c|c|c|c|c|c|}
\hline \multirow{2}{*}{$\begin{array}{l}\text { Crop stage } \\
\text { at simulated } \\
\text { hail event }\end{array}$} & \multirow{2}{*}{$\begin{array}{l}\text { Fungicide } \\
\text { treatment }\end{array}$} & igal dise & $\begin{array}{l}\text { TABLE } 6 \\
\text { ty (\% visu }\end{array}$ & $\begin{array}{l}\text { simulated } \\
\text { Site Year }\end{array}$ & nt for fiv & ars for corn. \\
\hline & & Ames '12 & Rake '12 & Ames '13's & Ames '14 & Kanawha' $14^{\mathrm{s}}$ \\
\hline \multirow[t]{6}{*}{ No hail } & $\mathrm{UTC}^{\mathrm{t}}$ & $1.8 \mathrm{a}^{\mathrm{u}}$ & $1.3 \mathrm{a}$ & $1.3^{\mathrm{v}}$ & $1.18 \mathrm{a}$ & 1.2 \\
\hline & $\mathrm{VT}^{\mathrm{w}}$ Immediate $\mathrm{x}$ & $1.1 \mathrm{~b}$ & $1.1 \mathrm{~b}$ & 1.2 & $0.90 \mathrm{c}$ & 1.2 \\
\hline & VT Deferredy & $1.0 \mathrm{~b}$ & $0.9 \mathrm{c}$ & 1.2 & $1.03 \mathrm{abc}$ & 1.3 \\
\hline & $\mathrm{R} 2^{\mathrm{z}}$ Immediate & $1.3 \mathrm{~b}$ & $1.1 \mathrm{~b}$ & 1.2 & $0.95 \mathrm{bc}$ & 1.1 \\
\hline & R2 Deferred & $1.2 \mathrm{~b}$ & $1.2 \mathrm{ab}$ & 1.2 & $1.08 \mathrm{ab}$ & 1.0 \\
\hline & $P$-value & 0.0256 & 0.0076 & 0.6317 & 0.0539 & 0.3965 \\
\hline \multirow[t]{4}{*}{ VT } & UTC & 0.9 & 0.9 & 1.2 & 1.0 & 1.1 \\
\hline & Immediate & 0.8 & 0.7 & 1.0 & 0.7 & 1.2 \\
\hline & Deferred & 1.0 & 0.8 & 1.2 & 1.0 & 1.1 \\
\hline & $P$-value & 0.3624 & 0.6799 & 0.4933 & 0.1522 & 0.3075 \\
\hline \multirow[t]{4}{*}{$\mathrm{R} 2$} & UTC & 1.1 & 0.7 & 1.1 & 1.1 & 1.2 \\
\hline & Immediate & 1.0 & 0.8 & 1.0 & 0.8 & 1.1 \\
\hline & Deferred & 0.9 & 0.7 & 1.4 & 1.0 & 1.0 \\
\hline & $P$-value & 0.4366 & 0.9853 & 0.1611 & 0.1602 & 0.6552 \\
\hline
\end{tabular}

${ }^{\mathrm{s}}$ These locations received natural hail across the experimental plot.

${ }^{\mathrm{t}} \mathrm{UTC}=$ untreated control.

${ }^{\mathrm{u}}$ Means followed by the same letter are not significantly different $(P=0.1)$.

${ }^{v}$ Means not followed by letters designates no significant difference $(P=0.1)$ among that particular group of means.

"Corn growth stage VT ("tasseling").

${ }^{\mathrm{x}}$ Immediate $=$ applications were sprayed 2 to 6 days (averaging 3 days) after a simulated hail event.

${ }^{\mathrm{y}}$ Deferred $=$ applications were sprayed 7 to 12 days (averaging 8 days) after a simulated hail event.

${ }^{\mathrm{z}}$ Corn growth stage R2 ("blister"). 
TABLE 7

Effect of simulated hail treatments on foliar fungal disease severity (\% visual) and yield within each of five site years on corn.

\begin{tabular}{|c|c|c|c|c|c|c|}
\hline \multirow[b]{2}{*}{ Effect } & \multirow{2}{*}{$\begin{array}{l}\text { Simulated hail } \\
\text { treatment }\end{array}$} & \multicolumn{5}{|c|}{ Site Year } \\
\hline & & Ames '12 & Rake '12 & Ames '13v & Ames '14 & Kanawha '14V \\
\hline \multirow{5}{*}{$\begin{array}{l}\text { Foliar disease } \\
\text { severity }(\%)\end{array}$} & No Hail VTw & $1.3 \mathrm{a}^{\mathrm{x}}$ & $1.1 \mathrm{a}$ & $1.2^{\mathrm{y}}$ & $1.0 \mathrm{ab}$ & 1.2 \\
\hline & No Hail R2z & $1.4 \mathrm{a}$ & $1.2 \mathrm{a}$ & 1.2 & $1.1 \mathrm{a}$ & 1.1 \\
\hline & Hail VT & $0.9 \mathrm{~b}$ & $0.8 \mathrm{~b}$ & 1.1 & $0.9 \mathrm{c}$ & 1.1 \\
\hline & Hail R2 & $1.0 \mathrm{~b}$ & $0.7 \mathrm{~b}$ & 1.1 & $1.0 \mathrm{bc}$ & 1.1 \\
\hline & $P$-value & 0.0004 & $<0.0001$ & 0.6254 & 0.0315 & 0.4804 \\
\hline \multirow[t]{5}{*}{ Yield (bu/acre) } & No Hail VT & $176.3 \mathrm{a}$ & $180.8 \mathrm{a}$ & $183.7 \mathrm{a}$ & $176.3 \mathrm{a}$ & $197.9 \mathrm{a}$ \\
\hline & No Hail R2 & $172.5 \mathrm{a}$ & $169.4 \mathrm{a}$ & $169.5 \mathrm{a}$ & $172.9 \mathrm{a}$ & $190.5 \mathrm{a}$ \\
\hline & Hail VT & $140.5 \mathrm{~b}$ & $129.5 \mathrm{~b}$ & $119.6 \mathrm{~b}$ & $134.5 \mathrm{c}$ & $147.0 \mathrm{~b}$ \\
\hline & Hail R2 & $122.8 \mathrm{~b}$ & $112.5 \mathrm{~b}$ & $132.3 \mathrm{~b}$ & $154.7 \mathrm{~b}$ & $150.4 \mathrm{~b}$ \\
\hline & $P$-value & 0.0067 & $<0.0001$ & $<0.0001$ & $<0.0001$ & $<0.0001$ \\
\hline
\end{tabular}

${ }^{\mathrm{v}}$ These locations received natural hail across the experimental plot.

w Corn growth stage VT ("tasseling").

${ }^{\mathrm{x}}$ Means followed by the same letter are not significantly different $(P=0.1)$.

${ }^{y}$ Means not followed by letters designates no significant difference $(P=0.1)$ among that particular group of means.

${ }^{\mathrm{z}}$ Corn growth stage R2 ("blister").

\begin{tabular}{|c|c|c|c|c|c|c|}
\hline \multicolumn{7}{|c|}{$\begin{array}{c}\text { TABLE } 8 \\
\text { Effects of fungicide timing on yield (bushels per acre) within simulated hail events for five site years for corn. }\end{array}$} \\
\hline \multirow{2}{*}{$\begin{array}{l}\text { Crop stage at } \\
\text { simulated hail event }\end{array}$} & \multirow{2}{*}{$\begin{array}{l}\text { Fungicide } \\
\text { treatment }\end{array}$} & \multicolumn{5}{|c|}{ Site year } \\
\hline & & Ames '12 & Rake '12 & Ames '13' & Ames '14 & Kanawha '14' \\
\hline \multirow[t]{6}{*}{ No hail } & $\mathrm{UTC}^{\mathrm{t}}$ & $174.7^{\mathrm{u}}$ & 165.6 & 171.9 & 173.2 & 188.8 \\
\hline & $\mathrm{VT}^{\mathrm{v}}$ Immediate $^{\mathrm{w}}$ & 175.8 & 191.7 & 194.4 & 166.4 & 217.6 \\
\hline & VT Deferred ${ }^{\mathrm{x}}$ & 178.3 & 185.1 & 184.9 & 189.3 & 187.4 \\
\hline & $\mathrm{R} 2 \mathrm{y}$ Immediate & 176.9 & 152.2 & 167.6 & 180.5 & 201.2 \\
\hline & R2 Deferred & 165.8 & 192.1 & 169.1 & 165.0 & 181.6 \\
\hline & $P$-value & 0.988 & 0.3464 & 0.4973 & 0.4386 & 0.4173 \\
\hline \multirow[t]{4}{*}{ VT } & UTC & 120.6 & 123.1 & 107.2 & 141.1 & 147.1 \\
\hline & Immediate & 127.8 & 123.0 & 117.7 & 118.0 & 141.6 \\
\hline & Deferred & 173.1 & 142.3 & 132.3 & 144.9 & 152.2 \\
\hline & $P$-value & 0.1349 & 0.5933 & 0.2803 & 0.4474 & 0.907 \\
\hline \multirow[t]{4}{*}{$\mathrm{R} 2$} & UTC & 115.5 & 116.1 & $151.7 \mathrm{a}^{\mathrm{Z}}$ & 151.3 & 145.7 \\
\hline & Immediate & 110.6 & 102.8 & $127.0 \mathrm{~b}$ & 159.7 & 144.3 \\
\hline & Deferred & 142.3 & 122.7 & $124.0 \mathrm{~b}$ & 152.9 & 161.2 \\
\hline & $P$-value & 0.1766 & 0.1299 & 0.0212 & 0.8015 & 0.6526 \\
\hline
\end{tabular}

$\mathrm{s}$ These locations received natural hail across the experimental plot.

${ }^{\mathrm{t}} \mathrm{UTC}=$ untreated control.

u Means not followed by letters designates no significant difference $(P=0.1)$ among that particular group of means.

${ }^{\mathrm{v}}$ Corn growth stage VT ("tasseling”).

${ }^{\mathrm{w}}$ Immediate $=$ applications were sprayed 2 to 6 days (averaging 3 days) after a simulated hail event.

${ }^{x}$ Deferred $=$ applications were sprayed 7 to 12 days (averaging 8 days) after a simulated hail event.

y Corn growth stage R2 ("blister").

${ }^{\mathrm{z}}$ Means followed by the same letter are not significantly different $(P=0.1)$.

resulted in a positive return for the fungicide application. Overall, combining the immediate and deferred applications around VT, fungicide applications provided a return of \$8.66/acre (Table 9). Fifty-two percent of the applications provided a positive economic return. However, the larger return from the applications came in the non-hail replications $(\$ 12.01 /$ acre $)$ versus the hail replications (\$5.24/acre). The percentage of positive returns was also slightly higher in the non-hail replications. However, there were sizable differences between the immediate and deferred fungicide applications. For the immediate applications, the overall return and the hail replication return were negative, but the nonhail replications had a positive return. The deferred applications showed a consistent positive return across the hail and non-hail scenarios at VT. While the non-hail VT deferred applications only returned $\$ 4.84 /$ acre and $55 \%$ of the replications showed positive returns, the hail VT deferred applications netted out \$42.37/acre and $65 \%$ of the replications had positive returns.
For the immediate and deferred applications around R2, the fungicide applications provided a negative return of $\$ 30.30 /$ acre. Only $33 \%$ of the applications provided a positive economic return. As with the VT replications, the better returns (but in this case, negative) from the applications came in the non-hail replications ( $-\$ 28.81 /$ acre) versus the hail replications $(-\$ 31.79$ /acre). The percentage of positive returns was the same across the hail and non-hail replications. Again, there were sizable differences between the immediate and deferred fungicide applications. For the immediate applications, the hail replication return was roughly $\$ 22.00 /$ acre less than the non-hail return and positive returns were only seen in $28 \%$ of the replications. In the deferred applications, the economic returns were improved for the hail scenario, but still with an average negative return. However, the non-hail returns were lowered. 


\section{CONCLUSIONS AND IMPLICATIONS FOR MANAGEMENT}

The lack of significant yield response observed between treatments receiving fungicide application after simulated hail and the untreated control in this study are consistent with results from Bradley and Ames (2010) and from other university studies testing fungicide use after actual hail events (Conley et al. 2010; Schleicher and Jackson-Ziems 2014; D. Smith, personal communication). These findings, coupled with the observation that foliar disease severity was lower in plots receiving simulated hail compared to non-hail control plots, supports the assertion from Wise and Mueller (2011) that the best chance for economic profitability from fungicide use in corn results when fungicides are applied for disease management when risk and actual disease occurrence is high.

The economic results mostly follow the yield results. However, the estimation of the returns shows a sizable advantage for fungicide applications around the VT stage. Given a hail event, the only application that averaged a positive return was the deferred application at VT. For that scenario, positive returns were seen nearly two-thirds of the time. Under the non-hail scenario, both the immediate and deferred applications resulted in positive returns, but the returns were higher for the immediate applications. Returns were negative across the board for the R2 applications, whether looking at hail or non-hail events or immediate or deferred application. These results are based on specific values for corn price and chemical and application costs. In order to account for situation-specific variability in these values, a calculator was developed that allows individuals to input their own price/cost information to help estimate response in a particular field using the yield data from this study. The calculator can be accessed at http://www.ipm.iastate.edu/corncalculator.

Foliar disease severity decreased at three site years in hail plots compared to non-hailed plots during the course of this study. Interestingly, the two site years that showed no statistical differences in foliar disease severity between hailed and non-hail plots both received natural hail during vegetative stages, thus nullifying an appropriate comparison. In light of this, if a defensive response to pathogens were elicited by hail injury, plants throughout the experimental plot would have been subjected to the trigger of this response at these two naturally hailed site years. Cheong et al. (2002) observed that plant wounding and pathogen response overlap in the model plant Arabidopsis, which backs the premise that a defensive reaction to pathogens is integrated with a response to wounding.

Our findings of lower amounts of disease in hailed plots compared to non-hail plots differ from what was observed by Bradley and Ames (2010) in one of the two site years in their study. Bradley and Ames used a hybrid moderately susceptible to gray leaf spot in their experiment and in 2007, disease severity was higher in hail plots (52\%) compared to non-hail plots (44\%). Gray leaf spot was found to be the primary disease that year, and fungicide treatment (across hail treatments) significantly lowered disease severity. During the years of our study, gray leaf spot was never one of the top diseases observed, and total foliar disease severity never approached the same levels Bradley and Ames observed in 2007. Thus, if induced disease resistance does occur in hail-injured plants, there might be a limitation to this protection due to hybrid susceptibility, weather conditions, or other causes. Regardless, this information does lend credit to the claim that fungicides are most useful when high disease risk situations exist due to these factors.

Another potential reason that less disease may have been observed in hailed plots involves data collection methods. For example, less leaf tissue was present in hailed plots, especially so

\begin{tabular}{|c|c|c|c|}
\hline \multicolumn{4}{|c|}{$\begin{array}{c}\text { TABLE } 9 \\
\text { Economic data for VT growth stage fungicide applications. }\end{array}$} \\
\hline & $\begin{array}{c}\text { At VT, All } \\
\text { applications }\end{array}$ & $\begin{array}{c}\text { At VT, } \\
\text { Immediate }^{x}\end{array}$ & $\begin{array}{c}\text { At VT, } \\
\text { Deferredy }\end{array}$ \\
\hline $\begin{array}{r}\text { Average return } \\
\% \text { above } \$ 0\end{array}$ & $\begin{array}{l}\$ 8.66 \\
52 \% \\
\text { Bushel gai }\end{array}$ & $\begin{array}{c}\text { Overall } \\
(\$ 6.66)^{\mathrm{Z}} \\
44 \% \\
\text { needed to br }\end{array}$ & $\begin{array}{c}\$ 23.61 \\
60 \% \\
\text { ak even }\end{array}$ \\
\hline With hail damage & & & \\
\hline Average return & $\$ 5.24$ & $(\$ 33.85)$ & $\$ 42.37$ \\
\hline$\%$ above $\$ 0$ & $49 \%$ & $32 \%$ & $65 \%$ \\
\hline Without hail damage & & & \\
\hline Average return & $\$ 12.01$ & $\$ 19.17$ & $\$ 4.84$ \\
\hline$\%$ above $\$ 0$ & $55 \%$ & $55 \%$ & $55 \%$ \\
\hline
\end{tabular}

${ }^{\mathrm{x}}$ Immediate $=$ applications were sprayed 2 to 6 days (averaging 3 days) after a simulated hail event.

${ }^{\mathrm{y}}$ Deferred $=$ applications were sprayed 7 to 12 days (averaging 8 days) after a simulated hail event.

${ }^{\mathrm{z}}$ Parenthesis denote a negative value.

\begin{tabular}{|c|c|c|c|}
\hline \multicolumn{4}{|c|}{$\begin{array}{c}\text { TABLE } 10 \\
\text { Economic data for } \mathbf{R} 2 \text { growth stage fungicide applications. }\end{array}$} \\
\hline & $\begin{array}{l}\text { At } \mathbf{R 2} \text {, All } \\
\text { applications }\end{array}$ & $\begin{array}{l}\text { At R2, } \\
\text { Immediatex }\end{array}$ & $\begin{array}{l}\text { At R2, } \\
\text { Deferredy }\end{array}$ \\
\hline $\begin{array}{r}\text { Average return } \\
\% \text { above } \$ 0\end{array}$ & $\begin{array}{l}(\$ 30.30)^{\mathrm{z}} \\
33 \% \\
\text { Bushel ge }\end{array}$ & $\begin{array}{c}\text { Overall } \\
(\$ 38.56) \\
28 \% \\
\text { n needed to br }\end{array}$ & $\begin{array}{c}(\$ 22.03) \\
38 \% \\
\text { ak even }\end{array}$ \\
\hline $\begin{array}{l}\text { With hail damage } \\
\text { Average return } \\
\% \text { above } \$ 0\end{array}$ & $\begin{array}{c}(\$ 31.79) \\
33 \%\end{array}$ & $\begin{array}{c}(\$ 49.50) \\
30 \%\end{array}$ & $\begin{array}{l}(\$ 13.14) \\
37 \%\end{array}$ \\
\hline $\begin{array}{r}\text { Without hail damage } \\
\text { Average return } \\
\% \text { above } \$ 0\end{array}$ & $\begin{array}{l}(\$ 28.81) \\
33 \%\end{array}$ & $\begin{array}{c}(\$ 27.06) \\
26 \%\end{array}$ & $\begin{array}{l}(\$ 30.47) \\
40 \%\end{array}$ \\
\hline
\end{tabular}

${ }^{\mathrm{x}}$ Immediate $=$ applications were sprayed 2 to 6 days (averaging 3 days) after a simulated hail event.

${ }^{\mathrm{y}}$ Deferred $=$ applications were sprayed 7 to 12 days (averaging 8 days) after a simulated hail event.

${ }^{\mathrm{z}}$ Parenthesis denote a negative value.

in 2012 and 2013 when string trimmers were used to damage plants. Low levels of disease may have been removed from the plant along with leaf tissue. Less plant canopy may have resulted in better airflow and drying of leaves, creating an environment less conducive to disease. Leaves injured by ice in 2014 retained most of their tissue, but were shredded and difficult to reconstruct during the disease rating process. Because exact storm conditions were not simulated with our methods, other factors may exist during a natural hailstorm that may also impact disease infection.

Corn is not the only crop where fungicides are considered after a hail event. Soybean, cranberry (Wells and McManus 2013), peas (NSDU-Dept. of Entomology. 2010), and wheat (Beck et al. 2002) are examples of other crops where fungicide use after hail is considered. In dry beans, recent research found no yield impact from fungicides applied one day after a simulated hail event (Mahoney and Gillard 2014). Nor did the researchers observe an increased "disease pressure" due to simulated hail in dry bean plots. Wells and McManus (2013) observed that azoxystrobin and copper hydroxide fungicides applied immediately following a simulated hail event did not reduce cranberry fruit rot; however, azoxystrobin did reduce disease in one out of seven trials.

Production practices (e.g., tillage), weather (e.g., humidity), hybrid resistance, and other factors influence disease; various factors may also affect fungicide efficacy. The authors acknowledge that the scope of this study is limited and thus 
different conditions may exist which could elicit varying results. Future investigations are needed to further illuminate the possibility that hail-injured crops experience less disease severity than those that are uninjured, particularly in years when risk of fungal disease is higher than that experienced during the course of this research.

The information from this study will equip farmers and agronomists to make more informed decisions about fungicide application at a critical time in crop production: after a major abiotic stress event. Our findings that yield of corn plants receiving hail midseason is not significantly affected by Headline AMP application, and that foliar disease risk is reduced in hailinjured plants, could decrease unjustified pesticide applications and save farmers money during an already difficult growing situation. And if farmers do choose to apply fungicide after hail, the economic findings could help provide a benefit through targeted fungicide applications when appropriate conditions exist, specifically pyraclostrobin + metcanozole application approximately eight days after a hail event at growth stage VT.

\section{ACKNOWLEDGMENTS}

Special thanks to the United States Department of Agriculture (USDA) National Institute of Food and Agriculture (NIFA) for funding this research through the Regional Integrated Pest Management Competitive Grants Program-North Central Region (NC-RIPM) Project no. IOWN176014; and to Asmus Farm Supply in Rake, IA, for additional project funding. With much appreciation to John Shriver for applying fungicides and harvesting plots; Josh Dunn, Brandon Kleinke, Stuart McCulloh, Warren Pierson, Matthew Schnabel, Kent Sisson, and Micah Smidt for assisting with plot establishment, maintenance, and data collection/handling; and to the employees of Asmus Farm Supply for their time and efforts in planting, maintaining, and harvesting plots in Rake, IA. Thanks to Jean Carlson Batzer, Melissa Irizarry, and Gladys Mbofung for critical review. A big thanks to the grocery store managers (especially Gary Gray at Hy-Vee in Ames, IA) who supplied many bags of ice to fuel the hail machine.

\section{LITERATURE CITED}

Abendroth, L. J., Elmore, R. W., Boyer, M. J., and Marlay, S. K. 2011. Corn growth and development. Ext. Publ. PMR 1009. Iowa State University Extension, Ames.

BASF Corporation. 2008a. Headline Fungicide Label. NVA 2008-04-0880327. BASF Corp., Research Triangle Park, NC.

BASF Corporation. 2008b. Headline Fungicide Corn Technical Information Bulletin. APN 4200819883021A. BASF Corp., Research Triangle Park, NC. Accessed from http://agproducts.basf.us/products/research-library/ headline-on-corn---technical-information-bulletin.pdf on 21 April 2015.

BASF Corporation. 2009. Headline Fungicide Plant Health Research Summary. APN-09-01-088-0021. BASF Corp., Research Triangle Park, NC.

Bayer CropScience. 2012. Stratego YLD Fungicide Label. US79851057D Bayer CropScience LP, Research Triangle Park, NC.

Beck, R., Deneke, D., Fanning, B., Guthmiller, D., Moechnig, M., Nixon, J., Szczepaniec, A., and Tande, C. 2002. iGrow: SDSU pest and crop newsletter, 11 May 2012 (diseases section). South Dakota State University Extension. Accessed from http://igrow.org/up/articles/ Pest_Crop_2012-05-11.pdf on 25 February 2015.
Bradley, C. A., and Ames, K. A. 2010. Effect of foliar fungicides on corn with simulated hail damage. Plant Dis. 94:83-86.

Cheong, Y. H., Chang, H., Gupta, R., Wang, X., Zhu, T., and Luan, S. 2002. Transcriptional profiling reveals novel interactions between wounding, pathogen, abiotic stress, and hormonal responses in Arabidopsis. Plant Physiol. 129:661-677.

Conley, S. P., Esker, P., and Gaska, J. 2010. Use of fungicides in hail-damaged crops. Pages 77-80 in: Proc. of the 2010 Wisconsin Crop Management Conference. Vol. 49. University of Wisconsin Extension, Madison.

NSDU-Dept. of Entomology. 2010. Crop and Pest Report (Fungicide and hail damaged peas). North Dakota State University Agric., Fargo. Accessed from http://www.ag.ndsu.edu/archive/entomology/ndsucpr/Years/2010/ July/1/ppath.htm on 25 February 2015.

Fernandez-Cornejo, J., Nehring, R., Osteen, C., Wechsler, S., Martin, A., and Vialou, A. 2014. Pesticide use in U.S. agriculture: 21 selected crops, 1960-2008. EIB-124. USDA, Economic Research Service, Washington, DC.

French-Monar, R. D. 2010. Is there a need to spray hail-damaged corn with a foliar fungicide? Publ. No. PLPA-Co010-03, AgriLIFE Extension Texas A\&M System.

Hefty, B. 2013. Foliar fungicide in soybeans and corn. AgPhD, IFA Productions, Inc., Baltic, SD. Accessed from http://www.agphd.com/blog/ ag-phd-newsletter/2013/05/27/foliar-fungicide-in-soybeans-and-corn/ on 22 April 2015.

Jackson-Ziems, T. 2014. Fungicide use in corn after hail or wind damage. CropWatch, University of Nebraska-Lincoln. Accessed from http:// cropwatch.unl.edu/archive/-/asset publisher/VHeSpfv0Agju/content/ fungicide-use-in-corn-after-hail-or-wind-damage on 6 February 2015.

Mahoney, K. J., and Gillard, C. L. 2014. Plant health and yield of dry bean not affected by strobilurin fungicides under disease-free or simulated hail conditions. Can. J. Plant Sci. 94:1385-1389.

NOAA-NCDC. 2006. Climate of Iowa. NOAA, National Climatic Data Center (NCDC), Kansas City, MO. Accessed from http://www.crh.noaa.gov/ images/dvn/downloads/Clim_IA_01.pdf.

Paul, P. A., and Munkvold, G. P. 2004. A model-based approach to preplanting risk assessment for gray leaf spot of maize. Phytopathology 94:13501357.

Plastina, A., Johanns, A., and Weets, S. 2015. 2015 Iowa Farm Custom Rate Survey. Ag Decision Maker File A3-10. Iowa State University Extension. Accessed from http://www.extension.iastate.edu/agdm/crops/pdf/a310.pdf on 6 August 2015.

Robertson, A. E., Munkvold, G. P., Hurburgh, C. R., and Ensley, S. 2011. Effects of natural hail damage on ear rots, mycotoxins, and grain quality characteristics of corn. Agron. J. 103:193-199.

Schleicher, C. M., and Jackson-Ziems, T. A. 2014. Evaluation of foliar fungicide and application timing on field corn following hail event at SCAL in Nebraska, 2013. Plant Disease Management Reports 8:FC185.

Syngenta Crop Protection. 2013. QuiltXcel Fungicide Label. SCP 1324A-L1J 0413 4026039. Syngenta Crop Protection, LLC, Greensboro, NC.

USDA-ARS. 2015. Interior Iowa Daily Grain Prices. Prepared by Iowa Department of Agriculture and Land Stewardship, Marketing Bureau, Des Moines. Accessed from http://search.ams.usda.gov/mndms/2015/08/ NW_GR11020150806.TXT on 6 August 2015.

USDA-FCIC. 2013. Corn loss adjustment standards handbook: 2014 and succeeding crop years. FCIC-25080. USDA-Federal Crop Insurance Corporation, Washington, DC.

Wells, L. D., and McManus, P. S. 2013. Effects of simulated hail events and subsequent fungicide applications on cranberry fruit rot incidence and yield. Plant Dis. 97:1207-1211.

Wise, K., and Mueller, D. 2011. Are fungicides no longer just for fungi? An analysis of foliar fungicide use in corn. APSnet Features. doi:10.1094/APSnetFeature-2011-0531.

White, D. G. 1999. Compendium of Corn Diseases, 3rd ed. American Phytopathological Society, St. Paul, MN. 